\title{
AEROMAGNETIC MAP OF THE YANTIC QUADRANGLE, BLAINE AND HILL COUNTIES, MONTANA \\ By
}

R. W. Johnson, Jr., E. R. King, and C. L. Long

GEOPHYSICAL INVESTIGATIONS

MAP GP-382

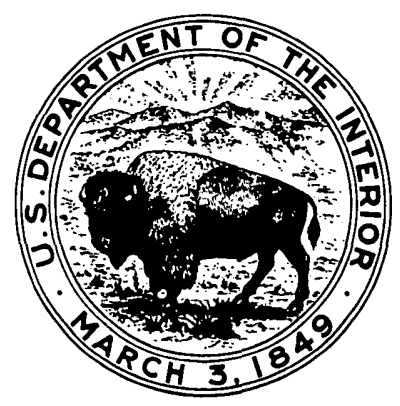

